\title{
Determination of aluminium in groundwater samples by GF-AAS, ICP-AES, ICP-MS and modelling of inorganic aluminium complexes
}

\author{
Marcin Frankowski • Anetta Zioła-Frankowska • \\ Iwona Kurzyca • Karel Novotný • Tomas Vaculovič • \\ Viktor Kanický • Marcin Siepak • Jerzy Siepak
}

Received: 23 June 2010 / Accepted: 19 December 2011 / Published online: 20 January 2011

(C) The Author(s) 2011. This article is published with open access at Springerlink.com

\begin{abstract}
The paper presents the results of aluminium determinations in ground water samples of the Miocene aquifer from the area of the city of Poznań (Poland). The determined aluminium content amounted from $<0.0001$ to $752.7 \mu \mathrm{g} \mathrm{L}^{-1}$. The aluminium determinations were performed using three analytical techniques: graphite furnace atomic absorption spectrometry (GF-AAS), inductively coupled plasma atomic emission spectrometry (ICP-AES) and inductively coupled plasma mass spectrometry (ICP-MS). The results of aluminium determinations in groundwater samples for particular analytical techniques were compared. The results were used to identify the ascent
\end{abstract}

\footnotetext{
M. Frankowski (凶) · A. Zioła-Frankowska •

I. Kurzyca · J. Siepak

Department of Water and Soil Analysis,

Faculty of Chemistry, Adam Mickiewicz University,

Drzymały 24, 60-613 Poznań, Poland

e-mail: Marcin.Frankowski@amu.edu.pl

K. Novotný · T. Vaculovič · V. Kanický

Department of Chemistry, Faculty of Science,

Masaryk University, Kotlářská 2,

61137 Brno, Czech Republic

\section{Siepak}

Department of Hydrogeology and Water Protection, Institute of Geology, Adam Mickiewicz University, Maków Polnych 16, 61-606 Poznań, Poland
}

of ground water from the Mesozoic aquifer to the Miocene aquifer in the area of the fault graben. Using the Mineql+ program, the modelling of the occurrence of aluminium and the following aluminium complexes: hydroxy, with fluorides and sulphates was performed. The paper presents the results of aluminium determinations in ground water using different analytical techniques as well as the chemical modelling in the Mineql+ program, which was performed for the first time and which enabled the identification of aluminium complexes in the investigated samples. The study confirms the occurrence of aluminium hydroxy complexes and aluminium fluoride complexes in the analysed groundwater samples. Despite the dominance of sulphates and organic matter in the sample, major participation of the complexes with these ligands was not stated based on the modelling.

Keywords Aluminium • Groundwater • Miocene aquifer - Aluminium complexes • Modelling - AAS · ICP

\section{Introduction}

Aluminium in ground water occurs at the concentration levels of 60 to $300 \mu \mathrm{g} / \mathrm{L}$ (KabataPendias and Pendias 1999). However, it should be underlined that such low concentrations of 
aluminium occur in unchangeable conditions including temperature, $\mathrm{pH}$ reaction, redox potential and the level of pollutant concentration. Due to the aluminium properties, including its amphoterism and the ability to transform, the change to any of the components affects the change of aluminium concentrations level, often by several ranks, which may result in a negative impact on the fauna and flora. The low concentrations of aluminium in groundwater are connected with the transformations of aluminosilicates in the active water exchange zone, where a significant amount of aluminium stays immobile in the structures of secondary minerals, and only a small part of the elements gets to the water. The processes influencing the aluminium activation in groundwater include the release of aluminium from minerals as a result of hydrolysis and dissolution, the reactions of cation exchange, the transfer of retained aluminium from pore water to groundwater in the soluble form, and the reactions of aluminium with other components of the solution (Macioszczyk and Dobrzyński 2002). The source of aluminium in groundwater are soluble complex bonds with dissolved fluoride $\left(\mathrm{AlF}^{2+}, \mathrm{AlF}_{2}^{+}, \mathrm{AlF}_{3}^{0}, \mathrm{AlF}_{4}^{-}\right)$, sulphate $\left(\mathrm{AlSO}_{4}^{+}\right.$, $\left.\mathrm{Al}\left(\mathrm{SO}_{4}\right)^{2-}\right)$, phosphate $\left(\mathrm{AlHPO}_{4}^{2+}, \mathrm{AlHPO}_{4}^{+}\right)$ligands and with low-molecular organic acids. Another source of aluminium is the so-called exchangeable aluminium fraction consisting of $\mathrm{Al}^{3+}$ ions and hydroxide complexes: $\mathrm{AlOH}^{2+}$, $\mathrm{Al}(\mathrm{OH})_{2}^{+}, \mathrm{Al}(\mathrm{OH})_{4}^{-}$adsorbed on the negatively charged surfaces of silt mineral particles and humus substances in soils and wastes. The form of aluminium occurring as complexes mainly depends on the reaction $\mathrm{pH}$, temperature, the concentration of organic and inorganic ligands such as: dissolved organic carbon, fluorides, sulphates, phosphates and suspended particles (Ščančar and Milačič 2006; Frankowski et al. 2010a, b; Frankowski and Zioła-Frankowska 2010). In the water marked by neutral reaction, aluminium dominates in the form of hydroxide complexes and organic complexes, while in lower concentrations it occurs in the form of fluoride and sulphate complexes (Ščančar and Milačič 2006; Zioła-Frankowska et al. 2009; Frankowski et al. 2009).
It should be underlined that the investigated water of the Miocene aquifer plays an important complementary role in supplying people with drinking water as well as with water used in households and industry. As a result of long-term pumping, a significant lowering of the table of the Miocene aquifer groundwater took place and the natural flow of this water was disturbed, which caused changes in hydrochemical zonality in the water-bearing layers. The ascent of saline water from the Mesozoic aquifer was observed in the study area, and the dislocation of the coloured water front within the Miocene aquifer was stated. The Miocene in the study area is formed by sands and brown coals which change upwards into the $\mathrm{mud} / \mathrm{silt}$ and silt formations (Górski and Przybyłek 1996). The groundwater in the Quaternary and Miocene aquifer is used in households and industry (Przybyłek 1986; Dąbrowski et al. 2007). The water at the Miocene aquifer occurs in the study area in the layers of fine-grained and muddy sands, which locally turn into mediumgrained, of the thickness of about several to $80 \mathrm{~m}$. The layers are separated by the discontinuous layer of muds and brown coals. The discussed level occurs at the depth of 50 to $150 \mathrm{~m}$ below the ground level.

By forming complexes with aluminium, ligands such as humic acids, fulvic acids, fluorides, phosphates and silicates decrease its toxicity, which depends on the form of aluminium occurrence in the environment and only appears in the case of hydroxy complexes, in particular $\mathrm{Al}(\mathrm{OH})_{2}^{+}$. Inorganic complexes of aluminium are more toxic than its organic complexes. The toxicity of aluminium usually decreases in the following order: polymer $\mathrm{Al}_{13}, \mathrm{Al}^{3+}, \mathrm{Al}(\mathrm{OH})^{2+}, \mathrm{Al}(\mathrm{OH})_{2}^{+}, \mathrm{Al}(\mathrm{OH})_{4}^{-}$and $\mathrm{AlSO}_{4}^{+}$. In connection with fluorides, aluminium and its organic complexes, as well as $\mathrm{Al}(\mathrm{OH})_{3}$ are considered harmless, while its labile forms such as $\mathrm{Al}^{3+}, \mathrm{AlOH}^{2+}, \mathrm{Al}(\mathrm{OH})_{2}^{+}$penetrate into the food chain and may be toxic for all living organisms (Boudot et al. 1994; Driscoll and Schecher 1990).

The analysis of aluminium in different components of the environment is a difficult task due to the physicochemical properties of this element. Aluminium determinations can then be performed by numerous methods, such as by 
Inductively Coupled Plasma Mass Spectrometry (ICP-MS), Graphite Furnace Atomic Absorption Spectrometry (GF-AAS) or Inductively Coupled Plasma Atomic Emission Spectrometry (ICPAES). GF-AAS has successfully been used to determine trace aluminium levels natural waters, seawater, river, soil and water (Danielsson and Sparén 1995; Mitrović et al. 1998; Salomon et al. 2000; Narin et al. 2004; Rezaee et al. 2010). Also ICP-MS method has been used in determination of aluminium in aqueous medium (water, lake water, limed lake, seawater, spring and forest soil waters; Bérubé and Brûlé 1999; Xia et al. 2005; Préndez and Carrasco 2003; Sjöstedt et al. 2009; Hills et al. 1999; Fairman et al. 1998; Rodushkin and Ruth 1997) and ICP-OES in determination aluminium in water samples (Rezaee et al. 2010) drinking water (Rossiter et al. 2010) or in boreal streams (Cory et al. 2009). The determination of aluminium by the ICP-MS technique is limited by the occurrence of interferences caused by other elements in the sample (matrix effects), due to which the aluminium determination using this technique is not fully justified. Therefore, the aluminium determinations and speciation analysis are commonly performed using the technique of graphite furnace atomic absorption spectrometry. Moreover, the aluminium speciation schemes are applied. The schemes are based on the speed of reaction with a complexing agent, the use of ionoselective electrode for the determination of fluorides, the ion exchange on ion-exchangeable resins and other (Bloom and Erich 1996).

The aims of the study were: (1) the comparison of analytical techniques (AAS and ICP) in aluminium determinations in groundwater samples of the Miocene aquifer, (2) defining the variability of aluminium occurrence in groundwater and the factors affecting the concentration of aluminium in this water, (3) applying the results of aluminium determinations in the identification of water ascent from the Mesozoic to the Miocene aquifer in the region of the fault graben, (4) modelling the occurrence of aluminium and aluminium complexes in the form of labile inorganic hydroxy, fluoride and sulphate complexes in the groundwater samples of the Miocene aquifer.

\section{Materials and methods}

\section{Sample collection}

The groundwater samples of the Miocene aquifer in the area of the city of Poznan were collected for the physicochemical analysis in the year 2006 from the exploited drilled wells (Fig. 1).

The non treated water for the analysis was collected after stabilising such parameters as: temperature, $\mathrm{pH}$ reaction, electrolytic conductivity. The measurements of temperature, $\mathrm{pH}$ reaction and electrolytic conductivity were taken using a multi-function Multi $197 \mathrm{i}$ meter produced by WTW (Weilheim, Germany), equipped with the following electrodes: $\mathrm{pH}$-Electrode SenTix 41 and TetraCon ${ }^{\circledR} 325$ produced by WTW (Weilheim, Germany). The measurement electrodes were placed in the flow-through cell produced by Eijkelkamp Agrisearch Equipment BV (Giesbeek, The Netherlands). The samples were collected and transported anaerobically in Nalgene ${ }^{\circledR}$ polyethylene bottles.

Groundwater conditions in the study area

Poznań is a city in west-central Poland with over 550,000 inhabitants. Located by the Warta River, it is one of the oldest Polish Cities, an important historical center and capital of the Wielkopolska District. There is a storeyed arrangement of groundwaters in the Poznań area within its boundaries, with the following aquifers (from top to bottom): the shallow aquifer, the Upper Quaternary aquifer (sandwiched between the glacial tills), the Wielkopolska Buried Valley aquifer (or the Middle Quaternary aquifer between the glacial tills), the Miocene aquifer with its Upper, Middle and Lower Zones), and the Oligocene aquifer (Dąbrowski et al. 2007; Przybyłek 1986; Górski 1989; Górski and Przybyłek 1996). Groundwater in the Miocene aquifer in the study area is stored in layers of fine-grained and muddy sands which locally turn into medium-grained. The thickness of sandy layers is changeable, from several to $80 \mathrm{~m}$. They are interlayered with the muddy seams and brown coals of discontinuous character. The Poznań Miocene aquifer contains confined 


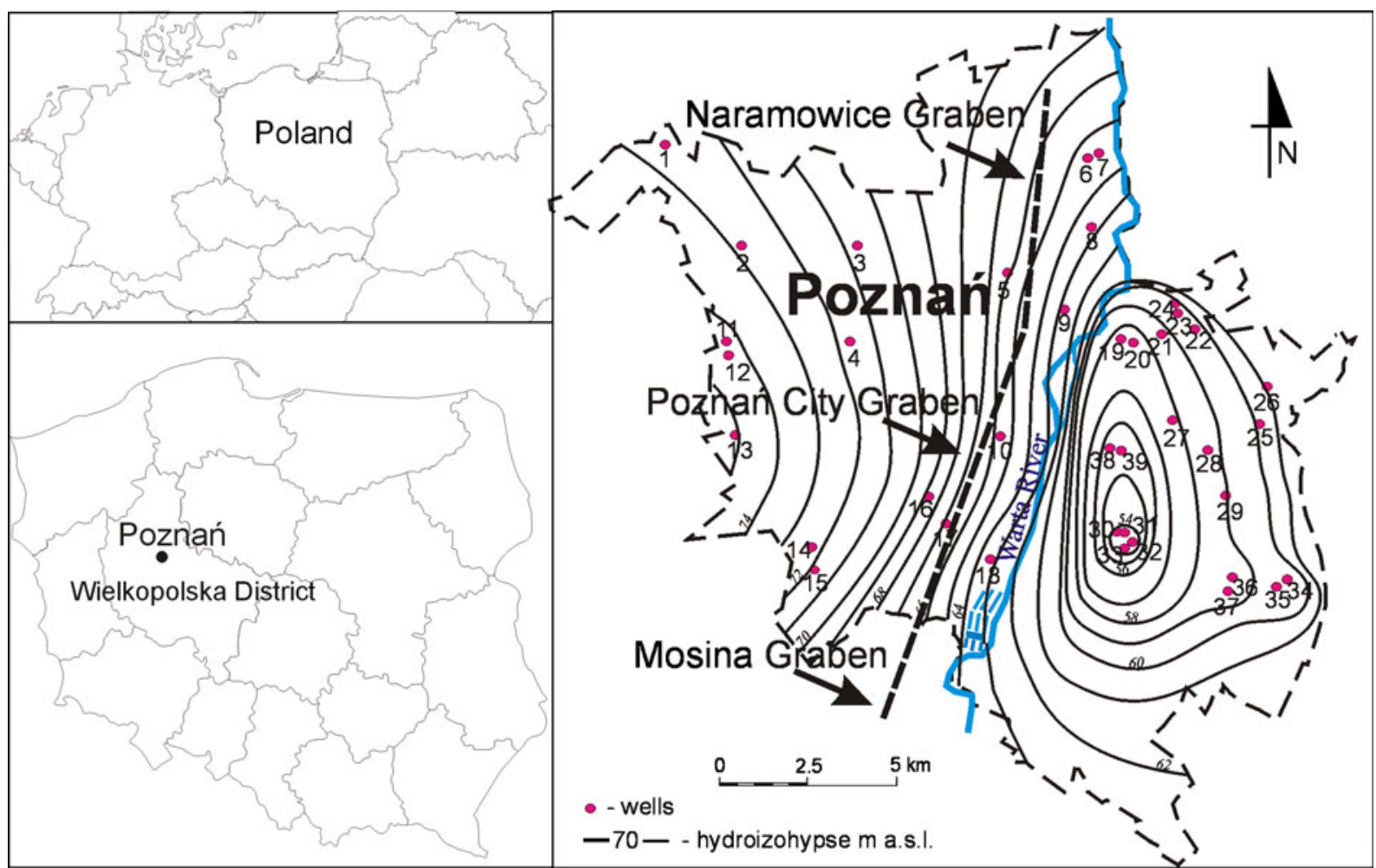

Fig. 1 Hydroizohypse map of ground water of Miocene and location of the sampling sites

groundwater-which is under subartesian conditions within the upland areas, and under the artesian conditions within the Warta River Valley. The confining bed is composed of an assembly of clay and muddy-clayey sediments of the Poznan Clay, Upper Miocene in age and variable in terms of thickness. In the study period (May-June, 2006), the water level in the study area was measured at the altitude of 54 to $75 \mathrm{~m}$ a.s.l. and showed a distinctly shaped cone of depression within the right-bank side of Poznań. The cone developed due to the extensive extraction of groundwater by the industrial plants.

\section{Analytical techniques in determination of $\mathrm{Al}$}

Four atomic absorption spectrometers with different types of atomization were used in the determination of aluminium in groundwater samples: GF-AAS produced by Perkin Elmer AAnalyst 300 (Norwalk, Connecticut, USA), GF-AAS produced by Varian (Mulgrave, Victoria, Australia),
ICP-MS spectrometer Agilent $7500 \mathrm{CE}$ produced by Agilent (Agilent, Japan) and ICP-OES spectrometer Jobin Yvon 170Ultrace (Jobin Yvon, France). The Spectra-20 Plus spectrometer is equipped with a GTA-96 electrothermal atomizer, which enables the temperature programming within the range from 40 to $3,000^{\circ} \mathrm{C}, \pm 1^{\circ} \mathrm{C}$, and the speed of $2,000^{\circ} \mathrm{C} / \mathrm{s}$. In order to inject the samples to the graphite furnace, the PSC-56 automatic sample injector was used. The AAnalyst 300 spectrometer is equipped with an electrothermal atomizer. The atomizer has the function of programming the temperature within the range from 20 to $3,000^{\circ} \mathrm{C}, \pm 1^{\circ} \mathrm{C}$. In order to inject the samples to the graphite furnace, the AS-72 automatic sample injector produced by Perkin Elmer was used. During the analysis, graphite furnaces with a Lvov platform, covered with pyrolytic graphite and HCL lamps were used. Particular phases of the temperature scheme of both AA spectrometers were subjected to optimization. The performed determinations in groundwater samples did not 
Table 1 Conditions of $\mathrm{Al}$ determinations by GF-AAS technique

${ }^{\text {a Spectra-20 Plus }}$ spectrometer

${ }^{\mathrm{b}}$ AAnalyst 300 spectrometer (explanation of $15+(30)$ mean that 15 [s] it is ramp time and $30[\mathrm{~s}]$ it is hold time)

\begin{tabular}{llll}
\hline Parameter & & GF-AAS $^{\mathrm{a}}$ & GF-AAS $^{\mathrm{b}}$ \\
\hline Wavelength & {$[\mathrm{nm}]$} & 309.3 & \\
Slit & {$[\mathrm{nm}]$} & 0.5 & 25 \\
Lamp current & {$[\mathrm{mA}]$} & 6 & 0.25 \\
Argon flow & {$\left[\mathrm{L} \mathrm{min}{ }^{-1}\right]$} & 3.0 & 300 \\
Drying & {$\left[{ }^{0} \mathrm{C}\right]$} & 120 & $15+(30)$ \\
Drying time & {$[\mathrm{s}]$} & 40 & 1350 \\
Ashing & {$\left[{ }^{0} \mathrm{C}\right]$} & 1000 & $1+(30)$ \\
Ashing time & {$[\mathrm{s}]$} & 2 & 2700 \\
Atomization & {$\left[{ }^{0} \mathrm{C}\right]$} & 2600 & $0+(5)$ \\
Atomization time & {$[\mathrm{s}]$} & 2 & 2700 \\
Cleaning & {$\left[{ }^{0} \mathrm{C}\right]$} & 2700 & 5 \\
Clearing time & {$[\mathrm{s}]$} & 2 & \\
Number of replications & - & 3 &
\end{tabular}

require the use of modifiers. The appropriately selected parameters of the GF-AAS spectrometer for the aluminium determinations have been listed in Table 1.

Quadrupole ICP-MS spectrometer Agilent 7500 CE (Agilent, Japan) is equipped by octopole reaction cell for removing of isobaric interferences. The solution was nebulized into doublepass Scott chamber using Babington nebulizer. Spray chamber was cooled to $2^{\circ} \mathrm{C}$. Sample flow rate was $0.4 \mathrm{ml} \mathrm{L}^{-1}$. ICP-MS conditions (summarized in Table 2) were optimized with respect to maximum $\mathrm{S} / \mathrm{N}$ ratio and minimum oxide formation. Integration time for isotope 27 measurement was set to $0.1 \mathrm{~s}$. ICP-AES spectrometer Jobin Yvon, 170Ultrace (Jobin Yvon, France) with laterally viewed plasma was used. Water samples were nebulized using Meinhard concentric nebulizer. The basic parameters of the ICP-AES and
ICP-MS spectrometers have been presented in Table 2.

Determinations of $\mathrm{F}^{-}$and $\mathrm{SO}_{4}^{2-}$

Concentrations of $\mathrm{F}^{-}$and $\mathrm{SO}_{4}^{2-}$ were determined by Dionex DX-120 Ion Chromatograph equipped with a CDM-3 conductivity detector, $25 \mu$ injection loop, and an AS14 analytical column $(4 \times$ $250 \mathrm{~mm})$, AG14 guard column $(4 \times 50 \mathrm{~mm})$, and ASRS-II 4-mm suppressor. The applied procedures made it possible to obtain reliable results with a good precision (RSD $<4 \%$ ) and accuracy (RSD $<6 \%$ ), which was confirmed by analyses of the certified reference material (EnviroMAT ${ }^{\mathrm{TM}}$ Ground Water, ES H 1; SCP SCIENCE, Canada) with a matrix corresponding to the samples under study. The recoveries were $102 \%$ for fluoride and $105 \%$ for sulphate, whereas method detection
Table 2 Conditions of $\mathrm{Al}$ determinations by the ICP-AES spectrometer (Jobin Yvon) and ICP-MS spectrometer (Agilent)

\begin{tabular}{llll}
\hline Parameter & & ICP-AES & ICP-MS \\
\hline Wavelength & {$[\mathrm{nm}]$} & 308.215 & - \\
& & 396.152 & 27 \\
Isotope & {$[\mathrm{W}]$} & - & 1500 \\
RF power & & & \\
Argon flow rates & {$\left[1 \mathrm{~min}^{-1}\right]$} & 12 & 15 \\
$\quad$-Plasma gas & & 0.4 & 0.21 \\
-Sheath gas & & 0.6 & 0.84 \\
-Carrier gas & {$\left[\mathrm{ml} \mathrm{min}^{-1}\right]$} & 1.0 & 0.4 \\
Sample flow rate & {$[\mathrm{s}]$} & 30 & 30 \\
Rinsing time & & 3 & 5 \\
Replicates & & &
\end{tabular}


Fig. 2 Results obtained for determination of aluminium in groundwater samples by GF-AAS (Varian, Perkin Elmer), ICP-AES and ICP-MS techniques

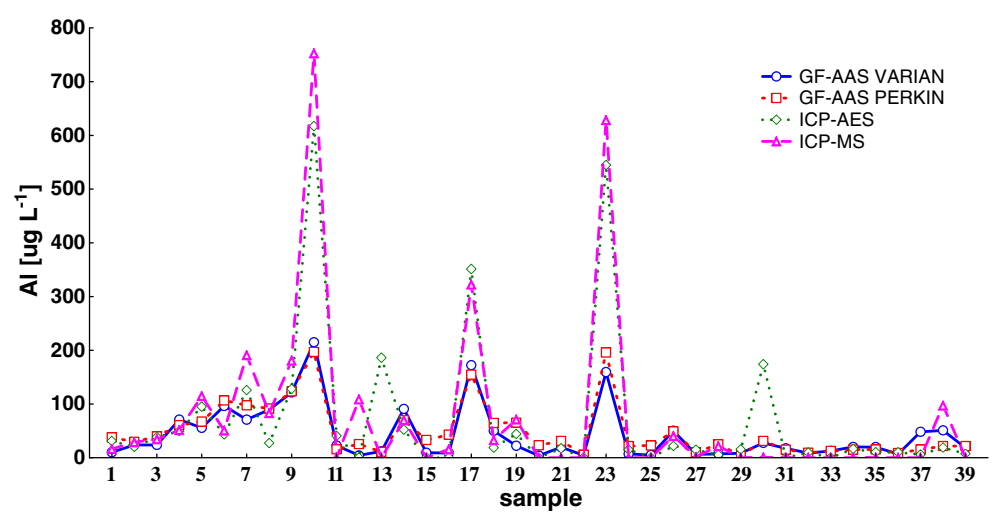

limits were $0.01 \mathrm{mg} \mathrm{L}^{-1}$ for $\mathrm{F}^{-}$and $0.01 \mathrm{mg} \mathrm{L}^{-1}$ for $\mathrm{SO}_{4}^{2-}$.

\section{Reagents}

The reagents used were analytically pure and water was deionized to a resistivity of $>18 \mathrm{M} \Omega$ in a Milli Q-RG apparatus (Millipore, France). During the determinations by the IC, GF-AAS, ICP-AES and ICP-MS techniques, standard solutions produced by Merck (Merck, Darmstadt, Germany), Fluka (Sigma-Aldrich, Steinheim, Switzerland), Astasol (Analytika Praha, Czech Republic) and the Czech Metrology Institute (CMI, Brno, Czech Republic) were used. The mobile phase for the determination of anions by the IC technique was prepared using the solutions produced by Merck (Merck, Darmstadt, Germany).

\section{Results and discussion}

Statistical analysis - comparison of analytical techniques

In order to compare the analytical techniques in terms of the results obtained for aluminium in the groundwater samples from the Miocene aquifer, statistical tests were used. For the determinations of aluminium $(n=39)$ performed using the three analytical techniques (GF-AAS - a Varian apparatus, GF-AAS - a Perkin Elmer apparatus, ICPMS and ICP-AES), the W Shapiro-Wilk test was used. The test $p$ values constituted $p<p$ of the significance level $p>p=0.05$, which indicates that the samples do not originate from the population with a normal distribution. The nonparametric Kruskal-Wallis test was then performed. The test $H$ value amounted to 5.505 at the significance level $p=0.138 . p>p=0.05$, which indicates the equal distribution of the compared analytical techniques. The results obtained in the Kruskal-Wallis test showed the lack of differences between the analytical techniques for the set of 39 aluminium determinations. The nonparametric Kolmogorov-Smirnov test for two variables in all possible combinations between the techniques was performed. The results obtained for particular groups (for $n=39$ in three analytical techniques) amounted to $p>0.1$ for the groups of GF-AAS techniques and the ICP-AES technique. At the significance level $\alpha=0.05$, there are no

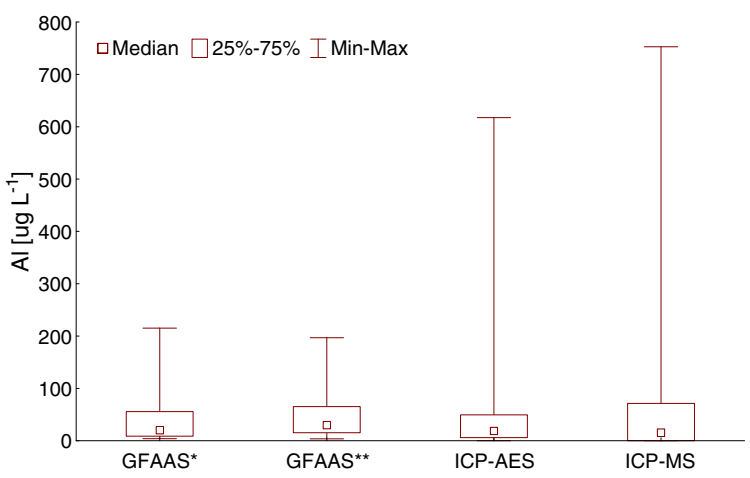

Fig. 3 The values of median, upper and lower quartile and concentration range of aluminium obtained in ground water samples of Miocene by analytical techniques (*Varian SpectraAA, **Perkin Elmer AAnalyst 300) 
grounds to reject the mean equality hypothesis in the investigated populations. For the ICP-MS and ICP-AES techniques, the value of $p>0.1$ in the Kolmogorov-Smirnov test was obtained. It should be underlined that the ICP and GF-AAS techniques had different injection systems which may influence the differences in results between these techniques. From the point of view of the environmental analytics, the results obtained for aluminium using different analytical techniques show too wide divergence, especially the results obtained using the ICP-MS and ICP-AES techniques. Despite the similar median values for all the analytical techniques for a certain number of samples, the minimum and maximum values in the ICP-MS technique significantly differ from the values obtained by the GF-AAS technique. Figure 2 presents the results of aluminium concentration analysis (GF-AAS, ICP) for the water collected from the wells at the Miocene aquifer. Figure 3 presents the basic statistical parameters for the studied group of samples $(n=39)$.
Based on the obtained study results, it may be stated that the trend of aluminium occurrence in particular samples is preserved (Fig. 2). The similar values between the two spectrometers were stated for GF-AAS. In order to graphically present the results of the analysis of samples collected at the Miocene aquifer, the map of concentration with the distribution network depending on the concentration were made using the Surfer 8 program (Golden Software Inc. USA) for GFAAS (Perkin Elmer) analytical techniques as an example (Fig. 4)

Based on the results of the analysis presented graphically on the map (Fig. 4), it may be stated that the results obtained for aluminium by means of different techniques are marked by the highest concentrations at points No. 7-10, 17, 23. At these points, the highest concentrations of chlorides in the Miocene aquifer groundwater were also stated (Siepak et al. 2006). This proves that, along with the saline water in the area of the influence of the tectonic structure, aluminium occurs in higher
Fig. 4 Concentration map of aluminium $\left[\mu \mathrm{g} \cdot \mathrm{L}^{-1}\right]$ determined by GF-AAS (Perkin Elmer)

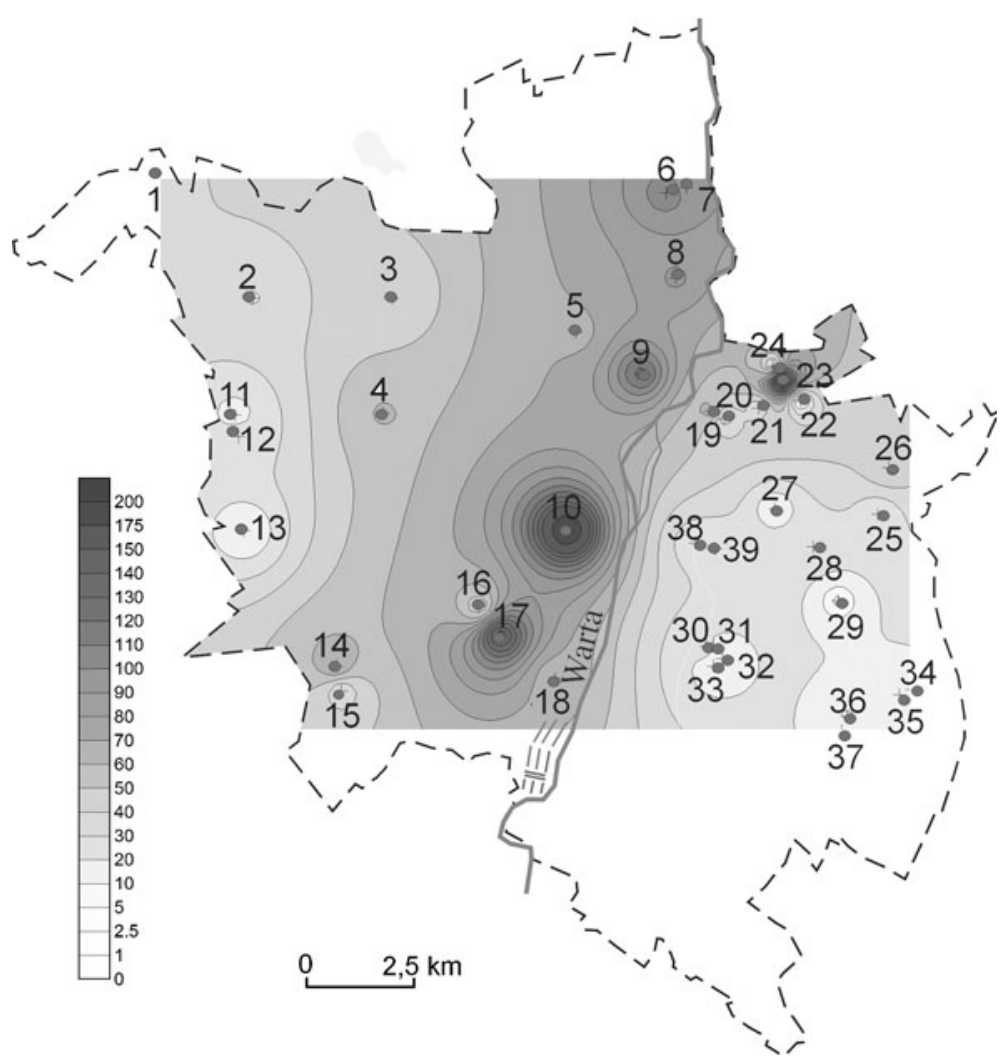


concentrations than in the other parts of the city of Poznań. The higher concentrations in the area of the tectonic fault graben may result from the ascent of water from the Mesozoic aquifer in the zone of hydraulically active tectonic faults caused by the pumping of water from the Miocene aquifer. At the same time, considering the fact that the water of this aquifer is isolated from the surface by a layer of boulder clays and silts of the Upper Miocene of the Poznan series, the pollution of this water with anthropogenic factors may be excluded. A greater threat is posed to the groundwater of the Miocene aquifer by extensive pumping of water taking place in the eastern part of the city, which has been graphically presented on the hydroizohips map (Fig. 1). Moreover, the intensive exploitation may cause the dislocation of the front of coloured water and the ascent of water marked by higher mineralization from the Mesozoic aquifer.
Table 3 The values of parameters used for modeling of aluminium forms in ground water samples (*A-upper, $\mathrm{B}$-middle, $\mathrm{C}$-down level of Miocene)

\begin{tabular}{|c|c|c|c|c|c|c|}
\hline Sample & $\begin{array}{l}\text { Water-bearing } \\
\text { horizon of Miocene* }\end{array}$ & $\begin{array}{l}\text { Temperature } \\
{\left[{ }^{\circ} \mathrm{C}\right]}\end{array}$ & $\mathrm{pH}$ & $\begin{array}{l}\mathrm{Al}_{\text {tot }} \\
{\left[\mu \mathrm{g} \mathrm{L}^{-1}\right]}\end{array}$ & $\begin{array}{l}\mathrm{F}^{-} \\
{\left[\mathrm{mg} \mathrm{L}^{-1}\right]}\end{array}$ & $\begin{array}{l}\mathrm{SO}_{4}^{2-} \\
{\left[\mathrm{mg} \mathrm{L}^{-1}\right]}\end{array}$ \\
\hline$\overline{1}$ & $\mathrm{C}$ & 13.4 & 6.60 & 37.79 & 0.46 & 10.99 \\
\hline 2 & B & 12.3 & 7.23 & 29.73 & 0.48 & 7.35 \\
\hline 3 & A & 12.1 & 6.90 & 39.76 & 0.53 & 5.76 \\
\hline 4 & B & 12.3 & 6.94 & 60.68 & 0.57 & 4.87 \\
\hline 5 & $\mathrm{C}$ & 11.9 & 6.61 & 67.14 & 0.67 & 0.09 \\
\hline 6 & $\mathrm{C}$ & 13.9 & 6.88 & 106.6 & 0.76 & 0.18 \\
\hline 7 & $\mathrm{C}$ & 13.2 & 7.16 & 97.47 & 0.23 & 112.1 \\
\hline 8 & $\mathrm{C}$ & 11.1 & 8.08 & 91.66 & 0.82 & 0.28 \\
\hline 9 & $\mathrm{C}$ & 13.1 & 6.85 & 123.5 & 0.68 & 1.21 \\
\hline 10 & $\mathrm{C}$ & 13.2 & 6.92 & 196.9 & 0.73 & 4.0 \\
\hline 11 & B & 12.2 & 7.18 & 15.77 & 0.39 & 0.49 \\
\hline 12 & $\mathrm{C}$ & 13.1 & 7.08 & 25.42 & 0.57 & 0.81 \\
\hline 13 & A & 13.2 & 7.00 & 10.9 & 0.31 & 7.07 \\
\hline 14 & A & 11.8 & 6.8 & 70.27 & 0.24 & 36.1 \\
\hline 15 & $\mathrm{~B}$ & 11.5 & 6.96 & 32.93 & 0.30 & 27.4 \\
\hline 16 & $\mathrm{~B}$ & 10.9 & 6.68 & 43.08 & 0.51 & 2.33 \\
\hline 17 & $\mathrm{C}$ & 15.7 & 6.66 & 154.7 & 0.56 & 5.5 \\
\hline 18 & $\mathrm{C}$ & 13.7 & 7.08 & 64.51 & 0.85 & 0.33 \\
\hline 19 & A & 13.5 & 6.6 & 65.24 & 0.54 & 0.33 \\
\hline 20 & B & 13.1 & 7.07 & 23.29 & 0.59 & 1.72 \\
\hline 21 & A & 12.1 & 6.86 & 31.38 & 0.66 & 0.03 \\
\hline 22 & A & 12.4 & 6.76 & 5.876 & 0.62 & 0.11 \\
\hline 23 & A & 12.0 & 6.75 & 195.8 & 0.66 & 0.07 \\
\hline 24 & A & 13.3 & 6.62 & 21.8 & 0.67 & 0.1 \\
\hline 25 & A & 12.3 & 6.77 & 22.71 & 0.58 & 0.23 \\
\hline 26 & A & 12.9 & 6.73 & 48.95 & 0.13 & 328 \\
\hline 27 & A & 13.1 & 6.54 & 10.43 & 0.63 & 0.08 \\
\hline 28 & A & 13.2 & 6.70 & 25.1 & 0.66 & 0.39 \\
\hline 29 & A & 10.8 & 6.61 & 3.71 & 0.69 & 0.04 \\
\hline 30 & B & 14.3 & 6.79 & 31.23 & 0.59 & 1.36 \\
\hline 31 & B & 13.9 & 6.67 & 15.12 & 0.58 & 0.52 \\
\hline 32 & B & 14.35 & 6.84 & 9.376 & 0.58 & 2.11 \\
\hline 33 & B & 14.4 & 6.81 & 12.37 & 0.57 & 3.67 \\
\hline 34 & B & 12.3 & 6.82 & 15.12 & 0.68 & 1.97 \\
\hline 35 & B & 13.0 & 6.88 & 15.50 & 0.69 & 2.72 \\
\hline 36 & B & 12.4 & 6.28 & 8.691 & 0.67 & 2.68 \\
\hline 37 & B & 12.4 & 6.20 & 15.31 & 0.62 & 3.09 \\
\hline 38 & A & 12.3 & 6.50 & 21.85 & 0.49 & 0.82 \\
\hline 39 & A & 12.5 & 6.71 & 21.78 & 0.52 & 0.04 \\
\hline
\end{tabular}


Aluminium determination and the comparison of analytical techniques

For all the analytical techniques applied in aluminium determinations, the analysis of the certified reference material Enviromat Ground Water ES-H-1 was performed and the recovery of $98-105 \%$ for all the techniques was obtained. The aluminium concentration in the Miocene aquifer occurred on the level from $<0.0001$ to $752.7 \mu \mathrm{g} \cdot \mathrm{L}^{-1}$ (Fig. 3).

\section{Modelling of aluminium complexes}

The $\mathrm{pH}$ reaction of water at the Miocene aquifer amounted to 6.60-8.08, which may be the evidence of the occurrence of mainly hydroxy aluminium complexes. The modelling was applied to the

Table 4 The results of calculated forms of aluminium complexes in [\%] from Mineql+ program (value 0 means complexes in molar concentration of $<\mathrm{E}-10)$

\begin{tabular}{|c|c|c|c|c|c|c|c|c|c|c|c|}
\hline Sample & $\mathrm{Al}^{3+}$ & $\mathrm{Al}(\mathrm{OH})_{2}^{+}$ & bf $\mathrm{Al}(\mathrm{OH})_{3}$ & $\mathrm{Al}(\mathrm{OH})_{4}^{-}$ & $\mathrm{AlOH}^{2+}$ & $\mathrm{AlF}_{2}^{+}$ & $\mathrm{AlF}_{3}$ & $\mathrm{AlF}^{+2}$ & $\mathrm{AlF}_{4}^{-}$ & $\mathrm{AlSO}_{4}^{+}$ & $\mathrm{Al}\left(\mathrm{SO}_{4}\right)_{2}^{-}$ \\
\hline 1 & 0 & 24.8 & 19.8 & 5.9 & 0 & 34.9 & 9.9 & 4.1 & 0 & 0 & 0 \\
\hline 2 & 0 & 12.9 & 43.2 & 42.2 & 0 & 1.2 & 0 & 0 & 0 & 0 & 0 \\
\hline 3 & 0 & 25.2 & 39.7 & 17.2 & 0 & 12.3 & 4.1 & 1.3 & 0 & 0 & 0 \\
\hline 4 & 0 & 21.9 & 37.9 & 18.9 & 0 & 14 & 5.9 & 1.2 & 0 & 0 & 0 \\
\hline 5 & 0 & 17.4 & 14.1 & 3 & 0 & 44 & 17.2 & 3.8 & 0 & 0 & 0 \\
\hline 6 & 0 & 19.6 & 29.7 & 19.3 & 0 & 20.3 & 9.3 & 1.5 & 0 & 0 & 0 \\
\hline 7 & 0 & 14.7 & 40.6 & 44 & 0 & 0 & 0 & 0 & 0 & 0 & 0 \\
\hline 8 & 0 & 0 & 16.5 & 82.8 & 0 & 0 & 0 & 0 & 0 & 0 & 0 \\
\hline 9 & 0 & 22.4 & 31.6 & 15.6 & 0 & 20.2 & 8.2 & 1.7 & 0 & 0 & 0 \\
\hline 10 & 0 & 21 & 34.8 & 20.8 & 0 & 15.4 & 6.5 & 1.2 & 0 & 0 & 0 \\
\hline 11 & 0 & 15 & 45.3 & 38 & 0 & 1.2 & 0 & 0 & 0 & 0 & 0 \\
\hline 12 & 0 & 17.2 & 41.3 & 34.7 & 0 & 4.5 & 1.7 & 0 & 0 & 0 & 0 \\
\hline 13 & 0 & 21.9 & 43.3 & 31.3 & 0 & 2.4 & 0 & 0 & 0 & 0 & 0 \\
\hline 14 & 0 & 35.1 & 43.2 & 14 & 0 & 5.3 & 0 & 1.3 & 0 & 0 & 0 \\
\hline 15 & 0 & 26.9 & 47.9 & 20.7 & 0 & 3.2 & 0 & 0 & 0 & 0 & 0 \\
\hline 16 & 0 & 26.4 & 25.1 & 4.8 & 0 & 30.4 & 9.5 & 3.4 & 0 & 0 & 0 \\
\hline 17 & 0 & 23.6 & 21.4 & 13.3 & 0 & 29.2 & 8.7 & 3.3 & 0 & 0 & 0 \\
\hline 18 & 0 & 15 & 35.9 & 35.1 & 0 & 8.6 & 4.7 & 0 & 0 & 0 & 0 \\
\hline 19 & 0 & 21.9 & 17.4 & 5.4 & 0 & 38.6 & 12.2 & 4.1 & 0 & 0 & 0 \\
\hline 20 & 0 & 17.5 & 41.1 & 33.7 & 0 & 5.1 & 2 & 0 & 0 & 0 & 0 \\
\hline 21 & 0 & 22.7 & 32.8 & 12.8 & 0 & 20.9 & 8.8 & 1.7 & 0 & 0 & 0 \\
\hline 22 & 0 & 22 & 25.3 & 8.5 & 0 & 29.5 & 11.8 & 2.5 & 0 & 0 & 0 \\
\hline 23 & 0 & 24.7 & 27.8 & 8.2 & 0 & 26.8 & 9.5 & 2.6 & 0 & 0 & 0 \\
\hline 24 & 0 & 15.6 & 13 & 4 & 0 & 44.5 & 18.8 & 3.6 & 0 & 0 & 0 \\
\hline 25 & 0 & 24 & 28.3 & 9.5 & 0 & 26 & 9.6 & 2.4 & 0 & 0 & 0 \\
\hline 26 & 0 & 40.3 & 39.8 & 15.4 & 0 & 2.3 & 0 & 1.3 & 0 & 0 & 0 \\
\hline 27 & 0 & 13.4 & 9.3 & 2.2 & 0 & 50.1 & 20.2 & 4.2 & 0 & 0 & 0 \\
\hline 28 & 0 & 19.1 & 19.1 & 6.8 & 0 & 36.4 & 15.1 & 3 & 0 & 0 & 0 \\
\hline 29 & 0 & 14.4 & 11.8 & 1.9 & 0 & 46.9 & 20.9 & 3.6 & 0 & 0 & 0 \\
\hline 30 & 0 & 22.4 & 27.5 & 16.1 & 0 & 23 & 8.6 & 2.1 & 0 & 0 & 0 \\
\hline 31 & 0 & 20.5 & 19.1 & 7.6 & 0 & 35.8 & 13.2 & 3.3 & 0 & 0 & 0 \\
\hline 32 & 0 & 22.1 & 30.4 & 20.5 & 0 & 18.2 & 6.8 & 1.7 & 0 & 0 & 0 \\
\hline 33 & 0 & 22.6 & 29 & 18.3 & 0 & 20.4 & 7.4 & 1.9 & 0 & 0 & 0 \\
\hline 34 & 0 & 21.6 & 28.4 & 10.7 & 0 & 25.8 & 11.2 & 2 & 0 & 0 & 0 \\
\hline 35 & 0 & 21.2 & 31.8 & 16.5 & 0 & 19.9 & 8.8 & 1.5 & 0 & 0 & 0 \\
\hline 36 & 0 & 4.5 & 1.7 & 0 & 0 & 61.8 & 26.2 & 5 & 0 & 0 & 0 \\
\hline 37 & 0 & 3.9 & 1.2 & 0 & 0 & 63.9 & 24.6 & 5.7 & 0 & 0 & 0 \\
\hline 38 & 0 & 18.6 & 11.7 & 2.1 & 0 & 47.4 & 14.4 & 5.3 & 0 & 0 & 0 \\
\hline 39 & 0 & 25 & 25.7 & 7.9 & 0 & 28.6 & 9.4 & 2.9 & 0 & 0 & 0 \\
\hline
\end{tabular}


aluminium complexes combined with fluorides and sulphates. The concentration of phosphates was so low and uncompetitive in relation to $\mathrm{F}^{-}$ and $\mathrm{SO}_{4}^{2-}$ that these ligands could be omitted in the modelling. The determination results obtained using the Perkin Elmer spectrometer (GF-AAS) were used. A simulation of aluminium forms based on the parameters presented in Table 3 was performed for all the groundwater samples. The ionic strength value was calculated based on the introduced concentration values of aluminium, fluorides and sulphates. The real temperature conditions of groundwater samples were adopted for the modelling.

For the groundwater samples of the Miocene aquifer, the modelling of aluminium forms which may occur in this environment was performed. In terms of aluminium toxicity, the values of this element obtained for groundwater are marked by low concentration. Hence, it may be assumed that they constitute the geochemical background. The fluorides, sulphates or phosphates present in the water can form complexes with aluminium mainly in the conditions of low $\mathrm{pH}$ reaction. However, taking into consideration the results obtained for the fluorides which prevail over the aluminium, aluminium complexes with fluorides may be highly competitive for the hydroxyaluminium forms. The results obtained based on the modelling have been presented in Table 4. The analysis of data obtained from the modelling confirms the lack of aluminium complexes with sulphates in the whole spectrum of samples. Even in sample No. 26, where the sulphate concentration amounted to $328 \mathrm{mg} \mathrm{L}^{-1}$, there are no conditions to form aluminium complexes $(\mathrm{pH}=6.73)$. It should be underlined that the $\mathrm{pH}$ conditions in the analysed water are not advantageous for the formation of complexes with inorganic and organic ligands. In the case of aluminium complexes with humuses, the samples with the high content of total organic carbon were subjected to modelling. No significant aluminium complexes with humuses were stated (Al-humuses values at $\left.\mathrm{E}^{-10} \mathrm{M}\right)$. The complexes of aluminium with fluorides are more competitive. The formation of aluminium complexes with $\mathrm{AlF}_{2}^{+}, \mathrm{AlF}_{3}, \mathrm{AlF}^{2+}$ was stated. For the majority of samples, the hydroxyaluminium complexes dominated.

The graph of the $\mathrm{pH}$ reaction and the molar proportion $\mathrm{Al}: \mathrm{F}$ (based on aluminium results obtained by GF-AAS Perkin Elmer analytical technique) drawn to illustrate the dependences resulting from the formation of aluminium complexes (Fig. 5).

Based on the obtained results, it may be stated that for the groundwater samples, the dominating complexes are hydroxyaluminium ones, which, due to the $\mathrm{pH}$ value, occur in each of the analysed samples. Along with the increase of $\mathrm{pH}$ reaction, the number of $\mathrm{Al}(\mathrm{OH})_{4}^{-}$complexes increases (sample No. 5). On the other hand, along with the decrease of $\mathrm{pH}$ reaction, which is advantageous for the formation of aluminium complexes
Fig. 5 Variability of concentration of $\left[\mathrm{H}^{+}\right]$ and molar ratio of aluminium to fluorides

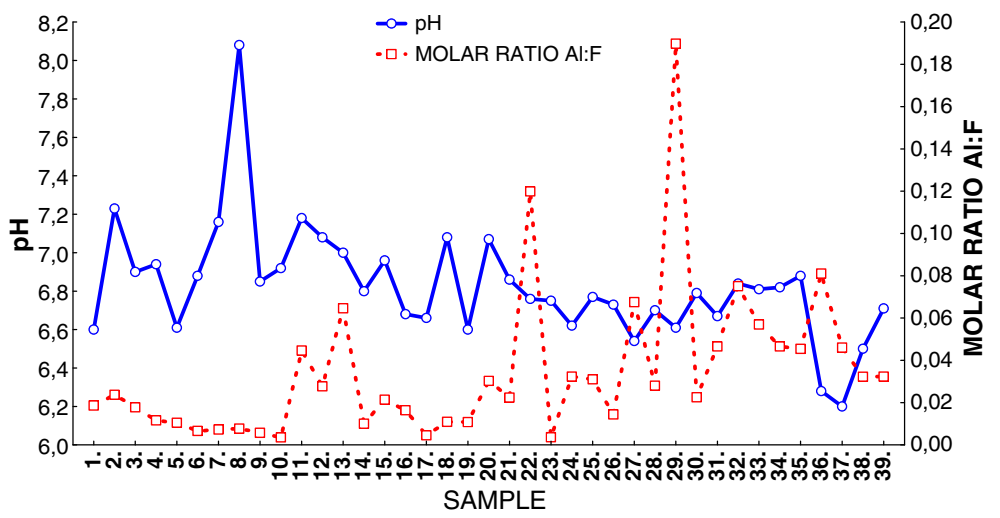

SAMPLE 
Fig. 6 Modelling of aluminium forms for sample No 8 in the range of reaction $5.5-8.0$

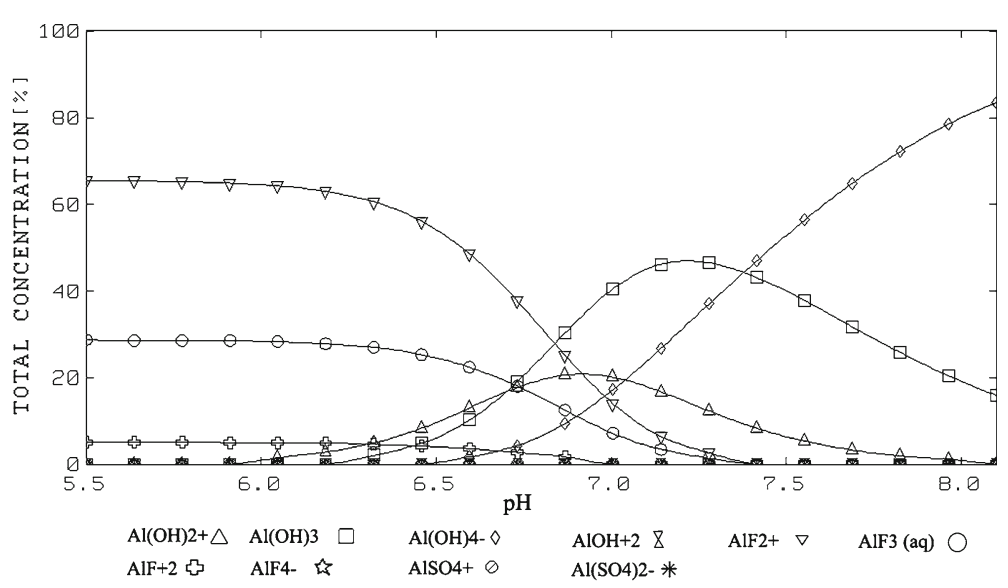

with fluorides, the $\mathrm{Al}(\mathrm{OH})_{4}^{-}$form does not occur and the whole available aluminium is bound by fluorides, mainly by $\mathrm{AlF}_{2}^{+}$(samples 36,37 ). Thus, the factor which conditions the occurrence of a given form of aluminium is the $\mathrm{pH}$ value. On the other hand, an equally important factor is the concentration of fluoride, sulphate, phosphate and organic ligands which are competitive in terms of forming complexes. The formation of complexes occurs in the conditions of the dominance of fluoride concentration over aluminium concentration. In the case of sulphates, the concentration must be very high (Frankowski et al. 2009). It should be underlined that the complexes of aluminium with fluorides are the most competitive and, as it results from the Mineql+ program mod- elling, they start forming at the $\mathrm{pH}$ of about 7 . The $\mathrm{AlF}_{2}^{+}>\mathrm{AlF}_{3}>\mathrm{AlF}^{2+}$ dominate, and at very high concentrations of aluminium the $\mathrm{AlF}_{4}^{-}$complexes begin to form. The Mineql+ program also enables the simulation of variable conditions, i.e., of $\mathrm{pH}$, the concentration of aluminium, fluorides and sulphates in order to estimate the aluminium fraction in given conditions. And so, for sample No. 8, where the highest concentration of fluorides was determined $\left(0.82 \mathrm{mg} \cdot \mathrm{L}^{-1}\right)$, the modelling was performed within the range of $\mathrm{pH}=5.5-8.0$ (Fig. 6).

Based on Fig. 6 it may be observed that the biggest changes in the formation of complexes occur in the range of $\mathrm{pH}=6.5-7.0$. At $\mathrm{pH}<$ 6.5 , the aluminium forms with fluorides dominate $\left(\mathrm{AlF}_{2}^{+}\right.$and $\left.\mathrm{AlF}_{3}\right)$. Then the range of $\mathrm{pH}$ reaction
Fig. 7 Modelling of aluminium forms for sample No 29

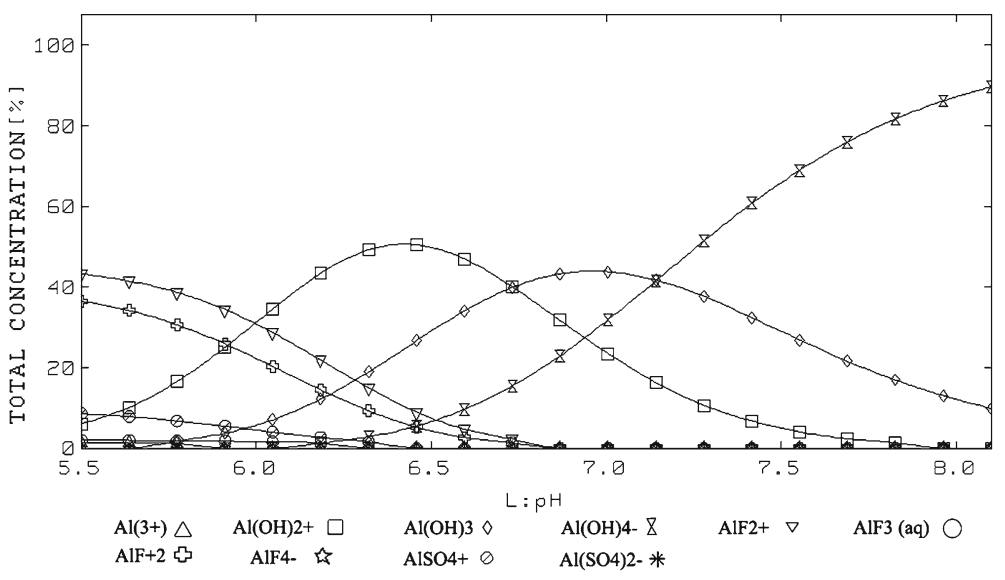


Fig. 8 Modelling of aluminium forms $\left(\mathrm{Al}-\mathrm{SO}_{4}\right.$ complexes) in the range of reaction 5.5-8.0 for concentration of fluorides $=0$

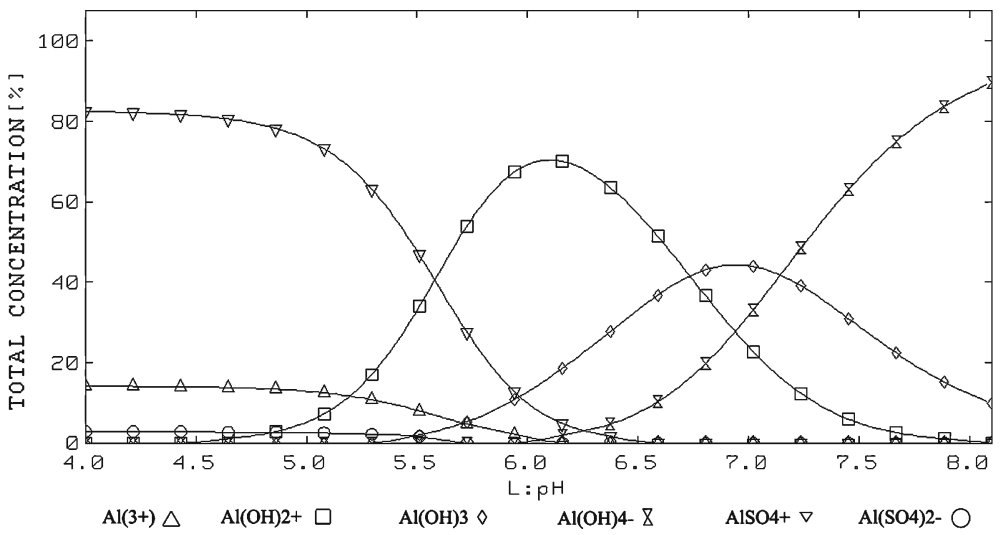

tion of the results. However, in the environmental analysis, due to the rich sample matrix, it is not possible to fully render the bonds of a complex occurring in a sample.

\section{Conclusions}

Based on the obtained results, it may be stated that the groundwater at the Miocene aquifer, which is isolated from the surface with a layer of boulder clays and the upper Miocene silts of the Poznań series, is to a small extent exposed to anthropogenic pollution. Definitely, a more serious threat to the groundwater of the Miocene aquifer, and especially to the lower Miocene aquifer, is posed by the ascent of water marked by higher mineralization from the Mesozoic aquifer in the area of the fault graben as well as the possible ascent of water caused by the intensified and concentrated exploitation of well fields in the eastern part of the Warta River, were a deep cone of depression has been formed.

The groundwater of the investigated waterbearing level indicates the low concentration of total aluminium and the occurrence of aluminium complexes with fluorides. Above $\mathrm{pH}=7.0$, the aluminium solubility decreases, which in consequence causes the decrease of concentration of the toxic $\mathrm{Al}^{3+}$ form. Below $\mathrm{pH}<7.0$, the $\mathrm{Al}^{3+}$ form starts to dominate, but the mainly inorganic ligands present in the sample form fluoride complexes, which is advantageous for decreasing the toxicity of this element. Fluoride ligands actually 
form complexes with the whole aluminium below $\mathrm{pH}=6.5$ present in the sample.

In the situation of condition simulation at fluoride concentration $=0$, the aluminium complexes with fluorides present in the sample dominate $\left(\mathrm{AlSO}_{4}^{+}\right)$. However, about $18 \%$ of aluminium remains in the $\mathrm{Al}^{3+}$ form.

Statistical analysis performed based on the obtained study results shows that the results obtained using the GF-AAS and ICP-AES techniques differ statistically from the results obtained from the ICP-MS spectrometer. It should be underlined that in the case of the study of that type of the environment, the dependences may be caused by the injection systems for ICP and GF-AAS analytical techniques.

Acknowledgement The research was supported by the Polish Ministry of Science and Higher Education through research grant No. 304374338 (2010-2011).

Open Access This article is distributed under the terms of the Creative Commons Attribution Noncommercial License which permits any noncommercial use, distribution, and reproduction in any medium, provided the original author(s) and source are credited.

\section{References}

Bérubé, D., \& Brûlé, D. G. (1999). A field aluminum speciation method to study the aluminium hazard in water. Fresenius Journal of Analytical Chemistry, 363, 566570.

Bloom, P. R., \& Erich, S. M. (1996). The quantitation of aqueous aluminium. In: G. Sposito (Ed.), The environmental chemistry of aluminium (pp. 363-419). Boca Raton: CRC.

Boudot, J. P., Becquer, T., Merlet, D., \& Rouiller, J. (1994). Aluminium toxicity in declining forests: A general overview with a seasonal assessment in a silver fir' forest in the Vosges mountains (France). Annales des Sciences Forestières, 51, 27-51.

Cory, N., Buffam, I., Laudon, H., Björkvald, L., Mörth, C. M., Köhler, S., et al. (2009). Particulate aluminium in boreal streams: Towards a better understanding of its sources and influence on dissolved aluminium speciation. Applied Geochemistry, 24, 1677-1685.

Dąbrowski, S, Górski, J., \& Przybyłek, J., (2007). The lowland sub-region of the Warta River; Regional hydrogeology of Poland. Fresh water (Vol. I, pp. 369-387). Warsaw: Polish Geological Institute, (in Polish).

Danielsson, L. G., \& Sparén, A. (1995). A mechanized system for the determination of low levels of quickly reacting aluminium in natural waters. Analytica Chimica Acta, 306, 173-181.

Driscoll, C. T., \& Schecher, W. D. (1990). The chemistry of aluminum in the environment. Environmental Geochemistry and Health, 12, 28-49.

Fairman, B., Sanz-Medel, A., Jones, P., \& Evans, E. H. (1998). Comparison of fluorometric and inductively coupled plasma mass spectrometry detection systems for the determination of aluminium species in waters by high-performance liquid chromatography. Analyst, 123, 699-703.

Frankowski, M., \& Zioła-Frankowska, A. (2010). Speciation analysis of aluminium and aluminium fluoride complexes by HPIC-UVVIS. Talanta, 82, 1763-1769.

Frankowski, M., Zioła-Frankowska, A., \& Siepak, J. (2009). Study of aluminium sulphate complexes of surface water and fractionation of aluminium from bottom sediment. Archives of Environmental Protection, 35, 55-67.

Frankowski, M., Zioła-Frankowska, A., \& Siepak, J. (2010a). Speciation of aluminium fluoride complexes and $\mathrm{Al}^{3+}$ in soils from the vicinity of an aluminium smelter plant by hyphenated High Performance Ion Chromatography Flame Atomic Absorption Spectrometry technique. Microchemical Journal, 95, 366372 .

Frankowski, M., Zioła-Frankowska, A., \& Siepak, J. (2010b). New method for speciation analysis of aluminium fluoride complexes by HPLC-FAAS hyphenated technique. Talanta, 80, 2120-2126.

Górski, J. (1989). The main hydrochemical problems of the Cainozonic aquifer located in central Wielkopolska (Great Poland). Scientific Bulletins of Stanisław Staszic Academy of Mining and Metallurgy, no.1308, Geology bulletin 45, Cracow (in Polish).

Górski, J., \& Przybyłek, J. (1996). Geological structure and ground water (pp. 23-43). The natural environment of the city of Poznań. Poznań (in Polish).

Hills, A., Grote, M., Janßen, E., \& Eichhorn (1999). Speciation of trace amounts of aluminum in percolating water of forest soil by online coupling HPLC-ICP-MS. Fresenius Journal of Analytical Chemistry, 364, 457461.

Kabata-Pendias, A., \& Pendias, H. (1999). Biogeochemistry of trace elements (pp. 192-198). Warszawa: Wydawnictwo Naukowe PWN.

Macioszczyk, A., \& Dobrzyński, D. (2002). Hydrogeochemistry of short turn-over time zone (pp. 322-324). Warszawa: Wydawnictwo Naukowe PWN (in Polish).

Mitrović, B., Milačič, R., Pihlar B., \& Simončič, P. (1998). Specification of trace amounts of aluminium in environmental samples by cation-exchange FPLCETAAS. Analusis, 26, 381-388.

Narin, I., Tuzen, M., \& Soylak, M. (2004). Aluminum determination in environmental samples by graphite furnace atomic absorption spectrometry after solid phase extraction on amberlite XAD-1180/pyrocathechol violet chelating resins. Talanta, 63, 411-418.

Préndez, M., \& Carrasco, M. A. (2003). Elemental composition of surfacewaters in the antarctic peninsula 
and interactions with the environment. Environmental Geochemistry and Health, 25, 347-363.

Przybyłek, J. (1986). Groundwater in the vicinity of the Poznań-Gostyń fault graben. Papers of Wrocław University of Technology. Wrocław. no. 49 (in Polish).

Rezaee, M., Yamini, Y., Khanchi, A., Faraji, M., \& Saleh, A. (2010). A simple and rapid new dispersive liquidliquid microextraction based on solidification of floating organic drop combined with inductively coupled plasma-optical emission spectrometry for preconcentration and determination of aluminium in water samples. Journal of Hazardous Materials, 178, 766-770.

Rodushkin, I., \& Ruth, T. (1997). Determination of trace metals in estuarine and sea-water reference materials by high resolution inductively coupled plasma mass spectrometry. Journal of Analytical Atomic Spectrometry, 12, 1181-1185.

Rossiter, H. M. A., Owusu, P. A., Awuah, E., MacDonald, A. M., \& Schäfer, A. I. (2010). Chemical drinking water quality in Ghana: Water costs and scope for advanced treatment. Science of the Total Environment, 408, 2378-2386.

Salomon, S., Giamarchi, P., Le Bihan, A., Becker-Roß, H., \& Heitmann, U. (2000). Improvements in the deter- mination of nanomolar concentrations of aluminium in seawater by electrothermal atomic absorption spectrometry. Spectrochimica Acta B, 55, 1337-1350.

Ščančar, J., \& Milačič, R. (2006). Aluminium speciation in environmental samples: A review. Analytical and Bioanalytical Chemistry , 386, 999-1012.

Siepak, M., Frankowski, M., Zioła, A., Kurzyca, I., \& Przybyłek, J. (2006). Chemistry in sustainable development (pp. 453-460) (in Polish).

Sjöstedt, C., Wällstedt, T., Gustafsson, J. P., \& Borg, H. (2009). Speciation of aluminium, arsenic and molybdenum in excessively limed lakes. Science of the Total Environment, 407, 5119-5127.

Xia, L., Hu, B., Jiang, Z., Wu, Y., Li, L., \& Chen, R. (2005). 8-Hydroxyquinoline-chloroform single drop microextraction and electrothermal vaporization ICP-MS for the fractionation of aluminium in natural waters and drinks. Journal of Analytical Atomic Spectrometry, 20, 441-446.

Zioła-Frankowska, A., Frankowski, M., \& Siepak, J. (2009). Development of a new analytical method for online simultaneous qualitative determination of aluminium (free aluminium ion, aluminium-fluoride complexes) by HPLC-FAAS. Talanta, 78, 623-630. 